\title{
The Impact of Greece as a Safe Tourism Destination (STD) in Tourist Psychology: Evidence from Spain
}

\author{
Meletios Andrinos ${ }^{1}$, Laura Juarez ${ }^{2}$ and Theodore Metaxas ${ }^{1 *}$ \\ ${ }^{1}$ Department of Economics, Lab. of Economic Policy and Strategic Planning,University of Thessaly, Greece \\ ${ }^{2}$ Department of Marketing and Communication,European University of Madrid, Spain
}

*Corresponding author: Theodore Metaxas, Department of Economics, Lab of Economic Policy and Strategic Planning,

University of Thessaly, Greece

\begin{abstract}
ARTICLE INFO
Received: 慧 September 10, 2020

Published: 㓞 September 22, 2020

Citation: Meletios Andrinos, Laura Juare, Theodore Metaxas. The Impact of Greece as a Safe Tourism Destination (STD) in Tourist Psychology: Evidence from Spain.

ABSTRACT

The main purpose of this paper is to examine and analyze the effect that the image of a place, in our case Greece, can have as a STD in the decision-making process for Spanish tourists' who will take summer holidays in 2020, amid covid19 pandemic. Data collected between $15^{\text {th }}$ of June and $31^{\text {st }}$ of July after the first wave of Covid-19 outbreak, when the Greek authorities promoted Greece as a Safe Tourist Destination to attract tourists. Results indicate that Spanish tourist consider Greece as a Safe Tourist Destination. The successful management of the Covid-19 pandemic compared to other countries and the low rates of Covid-19 cases strongly correlated to the image of Greece as a STD.
\end{abstract} Biomed J Sci \& Tech Res 30(4)-2020. BJSTR. MS.ID.004983.
Keywords: Health Safety;Tourist Psychology; STD; Covid19;Research

\section{Introduction}

\section{Tourism, Covid-19 Outbreak And Destinations' Health Safety}

On 31 December 2019, China's authorities reported to the WHO a pneumonia caused by a new virus. This new disease, coronavirus COVID-19, originated in Chinas city Wuhan was largely disregarded by the authorities of other countries despite the reports of its rapid dispersion [1]. According to WHO [2], coronavirus COVID-19 is an infectious disease that primary inflects the lungs of humans. It mostly affects kids, old aged people and people suffering with cardiovascular disease, cancer, respiratory disease, diabetes etc. The virus is spread in two main ways: through contact with infected peoples when they cough or sneeze and by touching surfaces that have the virus on it and then touches their eyes or mouth [3]. The virus spread quickly and on 11 March 2020 COVID-19, cases reported in 146 countries and WHO declared it as a pandemic. Without a vaccine or a specific antiviral treatment, the daily growing number of COVID19 cases in many countries obligated their authorities to implement non-pharmaceutical measures such as closing restaurants, bars, hotels and travel restrictions, border closure and even to implement general lockdown.
All those necessary health measures have lead on the collapse of the tourism chain. Flights canceled, airlines, hotels and restaurant closed and were on the verge of bankruptcy due to lack of clients and liquidity. Governments had to subsidize with state money all these companies and their employees. In fact, global tourism over the last twenty years has faced different health crises such as the SARS (2003) and the MERS (2015) outbreaks. None of them, not even the 2008 economic crisis, has dramatically affected the growth of the tourism sector (Figure 1) such as the coronavirus COVID-19 [1]. As of 31 July 2020, over 17 million COVID-19 confirmed cases and over 660,000 deaths were reported in 213 countries [2]. The panic among the public created by the spreading of COVID-19 pandemic in combination with the travel restriction, affected tourism and travel sector the most [3]. According to UNWTO [4], on the Q1 $202022 \%$ and the current scenarios point to declines of $58 \%$ to $78 \%$ for 2020 decreased arrivals (Figure 2). Nowadays, many countries are in the phase of reopening their economies. They have reopened schools and businesses and they try to restart their tourism economy in local scale and in limited international scale [1]. 


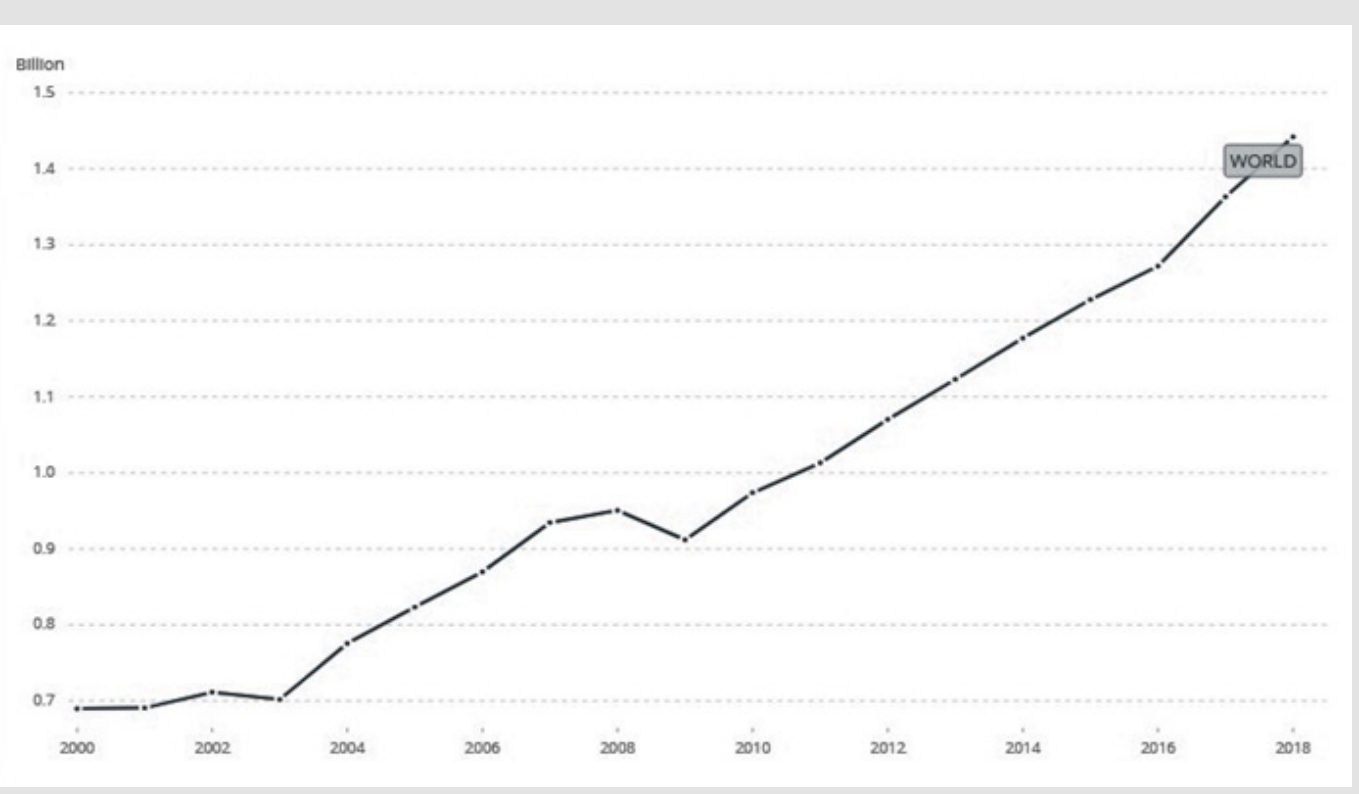

Figure 1: Tourism arrivals worldwide 2000-2018 [23].

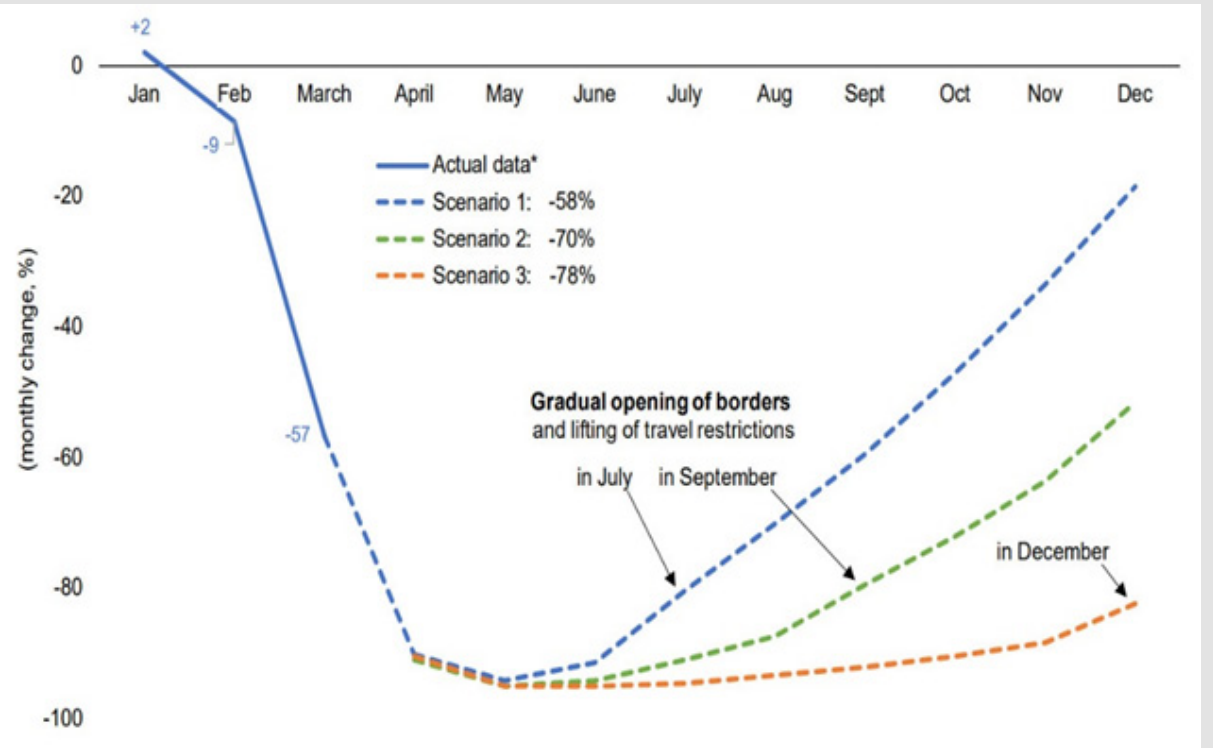

Figure 2: International tourism arrivals in 2020: UNWTO's scenarios [4].

To avoid all the negative impacts of the COVID19 outbreak [5], many destinations focus on tourism like business-as-usual [1]. However, the COVID-19 pandemic has changed tourists' perspective and awareness of safety and cleanliness issues [6]. The perceived health risk factors and the risk of contagious diseases influence the image of health destinations [7] and negative impression of the destination can be developed if the tourist feels unsafe [8]. Today the slogan "Safety sells in tourism" is more important than ever in the tourism and travel industry [9] and for this reason, many destinations have been promoted as Safe Tourist Destinations (STD) in order to attract tourists. According to Neuburger \& Egger
[10] tourism industry has to focus on reducing tourists' travel risk perception to bounce back quickly once the threat of COVID-19 decreases. Tourists can form reasonable safety expectations only when they have access to accurate and reliable information about the destination [11]. Thus, destinations have to communicate all the health cover and safety measures to ensure that tourists will feel safe. The purpose of the present study is to examine the factors that influence Greece's perceptions as a Safe Tourist Destination in the decision-making process for potential tourists from Spain, who will take summer holidays in 2020, amid Covid-19 pandemic. 


\section{Covid-19 in Spain}

According to the Ministery of Health, Consumption and Social Welfare [12], the following graphic shows the number of daily deaths caused by Covid-19 in Spain from March $1^{\text {st }}$ to July $31^{\text {st }}$ of 2020. At the end of July, the total number of deaths from Covid-19 in Spain reached the figure of 28,443 people. The daily death toll remained above 700 during the period from March $20^{\text {th }}$ to April $10^{\text {th }}$. Within the five months period shown bellow, April is the period with the highest mortality, with 16,162 deaths. The number of deaths drops considerably from the second half of May, registering less than 100 deaths a day. The month with the lowest incidence is June, due to the delayed effect of the nationwide lockdown issued on March $15^{\text {th }}$ figure 3. Although the Covid-19 has spread globally, it has not impacted all countries equally. Spain has been one of the countries in the world most affected by the coronavirus, both due to the number of infected, deaths and the collapse of health resources. It has also been one with the strictest lockdown and isolation measures, including the prohibition for children to go out during the state of alarm[13].

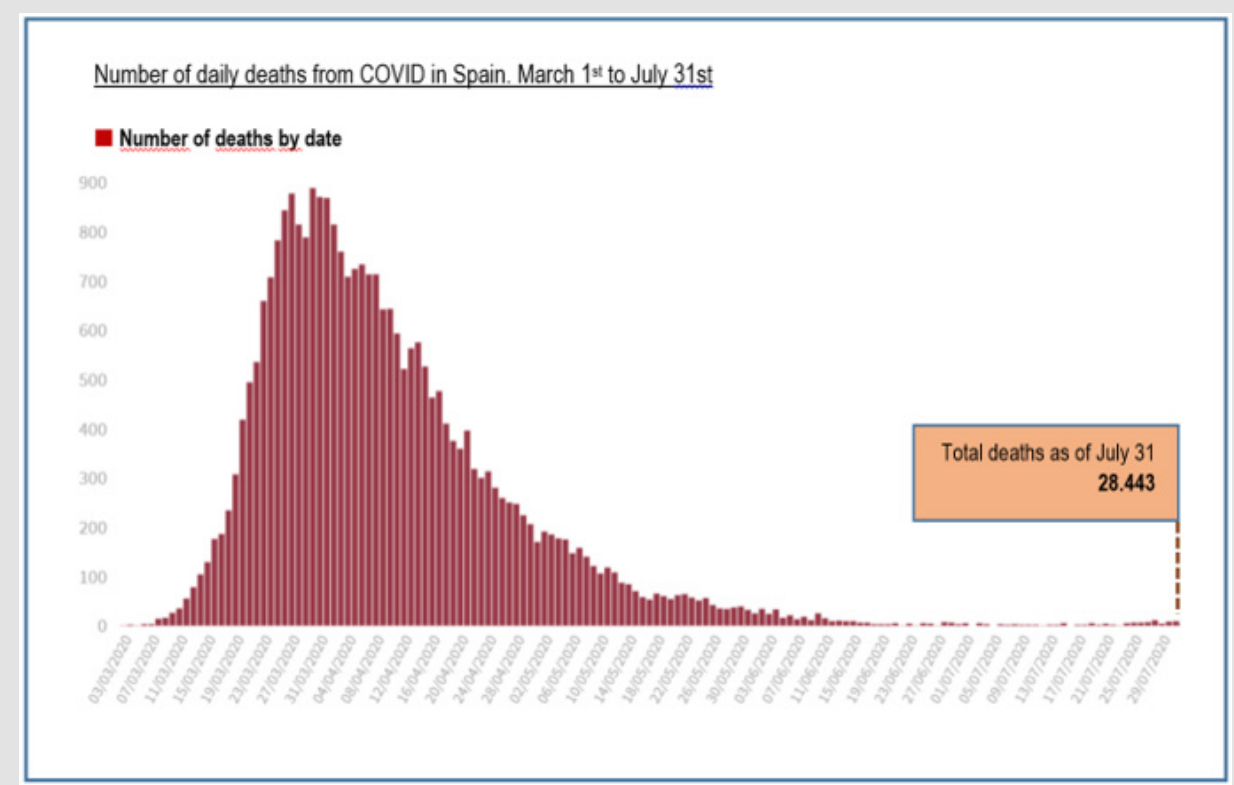

Figure 3: The situation of daily deaths from Covid-19 in Spain [25].

The experiences lived during the pandemic include different sources of stress for the population [14]. Previous studies carried out in stressful situations and emergencies make it possible to define which are the most significant variables of the psychological impact on people: fear of infection, not being able to cover basic needs, not having information and clear guidelines for action, feelings of frustration, anger and boredom [15] or the presence of economic problems [16]According to RodriguezRey et al.[17], those who suffer the most are women, young people, and those who consider themselves as a risk-population group. These authors strongly recommend to listen to the urgent call made by some European governments to look for a united approach to deal with the upcoming economic recession if we want to prevent a longlasting psychological suffering for the spanish society and people in other countries under similar circumstances.The Covid-19 pandemic is not over yet and the psychological effects related to this health crisis[18] are likely to have long lasting consequences after the pandemic is under control, which should be considered in future longitudinal studies [15].

\section{Research Method}

To explore Greece's perceptions as a Safe Tourist Destination this study conducted in Spanish tourists. In Greece, the first Covid-19 case reported on 26 February. The quarantine period in Greece lasted until May 4 when Greek authorities started the first phase of economy's restarting. The restarting of the tourism sector started on June 1 focusing on domestic tourism and on June 15 , the first foreign tourists arrived in Greece. On July 31, over 4,000 cases and 203 deaths from the COVID-19 reported in Greece [2]. It has commonly accepted that Greece has succeeded in preventing the first wave of the COVID-19 outbreak. In contrast, the dispersion of Covid-19 disease in Spain, as mentioned above, was rapid and on 25 March, the death toll surpassed that of mainland China, and only that of Italy was higher. As of 31 July 2020, almost 290,000 confirmed COVID-19 cases and over 28,500 reported in Spain [2]. Thus, it is interesting to examine Spaniards' perception, who were among those who suffered the most from the Covid-19 pandemic in Europe, regarding Greece as a Safe Tourist Destination. For this study, data collected between 15 June and 31 July 2020 using an online questionnaire developed in Spanish. Finally, 400 completely 
filled questionnaires used for analysis. The study focuses on Spanish tourists' perceptions regarding Greece as a Safe Tourist Destination which was measured used a 7-point Likert scale (1=Not at all and $7=$ To an extremely high extent). The measure items regarding the

\section{Results}

\section{Demographic Characteristics}

Table 1: Socio-Demographics profile of responders $(\mathrm{N}=400)$.

\begin{tabular}{|c|c|c|}
\hline $\mathbf{n}$ & Category & Distribution \\
\hline \multirow{2}{*}{ Gender } & Male & $170(42.5 \%)$ \\
\hline & Female & $230(57.5 \%)$ \\
\hline \multirow{5}{*}{ Age } & $18-24$ & $82(20.5 \%)$ \\
\hline & $25-34$ & $104(26 \%)$ \\
\hline & $35-49$ & $121(30.3 \%)$ \\
\hline & $50-65$ & $56(14 \%)$ \\
\hline & $>65$ & $37(9.3 \%)$ \\
\hline \multirow{4}{*}{ Education } & Primary School & $7(1.8 \%)$ \\
\hline & High School & $137(34.3 \%)$ \\
\hline & Graduate Degree & $182(45.5 \%)$ \\
\hline & Postgraduate Degree & $74(18.5 \%)$ \\
\hline \multirow{4}{*}{ Marital Status } & Single & $180(45 \%)$ \\
\hline & Married & $76(19 \%)$ \\
\hline & Divorced & $70(17.5 \%)$ \\
\hline & Married with children & $74(18.5 \%)$ \\
\hline \multirow{6}{*}{ Annual Household Income } & $<10.000 €$ & $25(6.3 \%)$ \\
\hline & $10.001-15.000 €$ & $20(5 \%)$ \\
\hline & $15.001-20.000 €$ & $112(28 \%)$ \\
\hline & $20.001-30.000 €$ & $158(39.5 \%)$ \\
\hline & $30.001-45.000 €$ & $50(12.5 \%)$ \\
\hline & $>45.001 €$ & $35(8.8 \%)$ \\
\hline \multirow{5}{*}{ Main Period of vacation } & April /May & $47(11.8 \%)$ \\
\hline & June / July & $77(19.3 \%)$ \\
\hline & August & $124(31 \%)$ \\
\hline & September / October & $126(31.5 \%)$ \\
\hline & Winter & $26(6.5 \%)$ \\
\hline \multirow{4}{*}{ Days of staying } & Less than 5 & $12(3 \%)$ \\
\hline & $5-10$ & $282(70.5 \%)$ \\
\hline & $11-15$ & $58(14.5 \%)$ \\
\hline & More than 15 & $48(12 \%)$ \\
\hline \multirow{2}{*}{ Sick from Covid-19 virus } & Yes & $21(5.3 \%)$ \\
\hline & No & $379(94.8 \%)$ \\
\hline \multirow{2}{*}{ Member of family or friend get sick } & Yes & $212(53 \%)$ \\
\hline & No & $188(47 \%)$ \\
\hline
\end{tabular}

Note: The percentages rounded up to one decimal point. Therefore, the percentage may not add to 100.0 because of rounding errors. assess the demographic profile of the sample SPSS version 21.0 applied. With respect to the gender, $57.5 \%$ were female responders. $56.3 \%$ of the responders were between $25-49$ years old and $45.5 \%$

To process the descriptive statistics on the collected data and had a graduate degree. The majority of the responders (45.0\%)

factors that influence tourists perception about Greece as a Safe Tourist Destination were measured in a 7-point Likert scale with $1=$ less important and $7=$ most important. All items taken from previous studies [1,19-22]. were singles and 39.5\% had 20,001 - 30,000€ personal annual income. Main period of responders' vacation is between August and October $(62.5 \%)$ and their stay period in the tourist destination is 
between 5 to 10 days (70.5\%). It is essential to mention that $94.8 \%$ did not sick from Covid-19 virus, but 53\% had a member of their family who gets sick. Table 1 outlines all the main sociodemographic characteristics of the responders.

\section{Greece as a Safe Tourist Destination}

The study's results confirm that Spanish tourists mind Greece as a health safe destination. Figure 4 indicates that $72.3 \%$ of Spanish tourist consider Greece as a Safe Tourist Destination. According to the mean score of each factor, for the Spaniards, the "consciousness and discipline of the citizen with the rules and regulations", "the highly trained medical and nursing professionals" and the "commitment on maintaining an unaffected brand name in terms of safety" considered the most significant factors that name Greece a Safe Tourist Destination. On the other hand, the less significant factors are their "prior travel experiences in Greece" and "how safe one can be under the COVID-19 circumstances" and "the access to information and advertising campaigns about how safe is to travel to Greece". Table 2 indicate the means score results for the factors that name Greece a safe destination.However, the results indicate that that Greece's image as a Safe Tourist Destination is strongly correlated (values greater than .7) with the factors of "Successful management of the COVID-19 pandemic compared with other countries" and the "Low rates of coronavirus infection across the country". In contrast, there are no correlations between the image of STD and factors, whichrelated to the trust in the implementation of health protocols by businesses or C-level tourism professionals or with the highly trained medical and nursing professionals.

Figure 4: Greece as a Safe Tourist Destination (Spaniards perceptions).

Table 2: Factors that name Greece a safe tourist destination.

\begin{tabular}{|c|c|c|c|}
\hline Factor & Mean & SD & $\begin{array}{l}\text { Pearson Correlation to "Greece a } \\
\text { Safe Tourist Destination" }\end{array}$ \\
\hline Cx2. Successful management of the COVID-19 pandemic compared with other countries & 5.140 & 1.0622 & $.781^{* *}$ \\
\hline Cx3. Low rates of coronavirus infection across the country & 5.085 & 1.0101 & $.710^{* *}$ \\
\hline Cx4. Low coronavirus death rate across the country & 5.130 & 1.0372 & $.633^{* *}$ \\
\hline Cx5. Well-developed health care system and infrastructure across country & 4.945 & 1.0511 & $.414^{* *}$ \\
\hline Cx6. Highly trained medical and nursing professionals & 5.303 & 1.1131 & $.397^{* *}$ \\
\hline $\begin{array}{c}\text { Cx7.Consciousness and discipline of the citizens as to the compliance with rules and } \\
\text { regulations }\end{array}$ & 5.383 & 1.0974 & $.399 * *$ \\
\hline Cx8. Safe, well-organized and modern tourism infrastructure & 5.120 & 1.0115 & $.467^{* *}$ \\
\hline Cx9. Trust in the implementation of health protocols by business & 4.910 & 1.1068 & $.398^{* *}$ \\
\hline $\begin{array}{c}\text { Cx10. Trust in the implementation of health protocols by C-level tourism executives and } \\
\text { professionals }\end{array}$ & 4.983 & 1.0630 & $.382^{* *}$ \\
\hline $\begin{array}{c}\text { Cx11. Trust in the implementation of health protocols by means of transport and } \\
\text { transport infrastructure }\end{array}$ & 4.893 & 1.0648 & $.362^{* *}$ \\
\hline Cx12. Locating travel destinations in the country, reporting zero cases of COVID-19 & 4.973 & .9946 & $.486^{* *}$ \\
\hline
\end{tabular}




\begin{tabular}{|c|c|c|c|}
\hline Cx13. Trust in good cooperation between business and health care system & 4.838 & 1.1703 & $.422^{* *}$ \\
\hline $\begin{array}{l}\text { Cx14. Trust in good cooperation between business and the general secretariat for civil } \\
\text { protection }\end{array}$ & 4.743 & 1.1682 & $.438^{* *}$ \\
\hline $\begin{array}{l}\text { Cx15. Greece is a safe European country in full compliance with the health protocols set } \\
\text { out in the European Union }\end{array}$ & 4.700 & 1.1372 & $.463^{* *}$ \\
\hline $\begin{array}{l}\text { Cx16. In Greece one can combine safe travel experience with unique moments and } \\
\text { unforgettable vacation experiences }\end{array}$ & 5.230 & 1.0955 & $.622^{*}$ \\
\hline $\begin{array}{l}\text { Cx17. Advertising Campaigns and information I had access to about how safe it is to } \\
\text { travel to Greece }\end{array}$ & 4.520 & 1.2840 & $.426^{* *}$ \\
\hline $\begin{array}{l}\text { Cx18. I 've been to Greece before and I know firsthand that I can be safe even under } \\
\text { COVID-19 circumstances }\end{array}$ & 4.343 & 1.5333 & $.526^{* *}$ \\
\hline $\begin{array}{l}\text { Cx19. Greece is a top travel destination globally, committed to maintain its brand name } \\
\text { unaffected this year as well as in terms of safety }\end{array}$ & 5.248 & 1.1509 & $.540^{* *}$ \\
\hline $\begin{array}{l}\text { Cx20. Trust in the safety and precautionary measures introduced by the Greek } \\
\text { Government concerning tourism business sector }\end{array}$ & 4.785 & 1.1300 & $.433^{* *}$ \\
\hline $\begin{array}{c}\text { Cx21. Trust in the policies and measures concerning tourism introduced by the } \\
\text { European Union }\end{array}$ & 4.620 & 1.1997 & $.500^{* *}$ \\
\hline
\end{tabular}

Note:**Correlation is significant at the 0.01 level (2-tailed).

\section{Discussion and Conclusions}

The present study is the first attempt to investigate Greece's image as a Safe Tourist Destination amid the Covid-19 pandemic and the factors that affect it. The result indicates that Greece, after the successful management of the first wave of the Covid-19 outbreak, considered a Safe Tourist Destination for international tourists, in our case Spaniards. In health crisis such as the Covid-19 pandemic tourism sector is affected the most [1] because tourism supply and demand decline dramatically [23]. Providing health safe destinations' environment may attract tourists because they feel less fear and anxiety for their health. An important factor that can be used by destinations to promote safety is social media $[24,25]$. According to the findings, Greece, as a Safe Tourist Destination, should use and promote the successful management of the Covid-19 outbreak compared with other countries, especially with those with the same characteristics and the low rates of coronavirus infections across the country to attract more tourists. Further, the Greek authorities and the tourism businesses must be ready to manage tourists' high flow in the high season. The image of a Safe Tourist Destination can easily change because it is related to the country's numbers of Covid-19 cases. Dramatically increasing numbers of Covid-19 cases could damage this image, which can lead to dissatisfied tourists that their expectations did not meet.

Despite contributing to the knowledge regarding the destinations' health safety image towards the Covid-19 pandemic, this study has several limitations. We must mention that questionnaires collected in a period (15th June - 31st July) that tourist flows in several destinations were limited and there was no evidence about the impacts on the coronavirus contagion after the travel bans period. In addition, the results based on the perceptions of Spanish tourists toward Greece. A wider cross-border research on Greece's image as a Safe Tourist Destination suggested so the result could generalized. Future research could also focus on tourists' psychology and their perceptions regarding destinations, and how health safety, on the differences in the tourists' decisionmaking process, between safe health destinations and destination with high numbers of Covid-19 cases. Finally, research could focus on the tourists' preferences on the on-site experiences and their overall satisfaction regarding all the health safety measures.

\section{Conflict of Interest}

The author(s) reported no potential conflict of interest.

\section{References}

1. Gössling S, Scott D, Hall C M (2020) Pandemics, tourism and global change: a rapid assessment of COVID-19. Journal of Sustainable Tourism $1-20$.

2. (2020) WHO Coronavirus Disease (COVID-19) Dashboard. WHO.

3. Bakar N A, Rosbi S (2020) Effect of Coronavirus disease (COVID-19) to tourism industry. International Journal of Advanced Engineering Research and Science 7(4): 189-193.

4. (2020) International Tourist Numbers Could Fall $60-80 \%$ in 2020 , UNWTO Reports. World Tourism Organization (UNWTO).

5. Sigala M (2020) Tourism and COVID-19: Impacts and implications for advancing and resetting industry and research. Journal of Business Research, 117: 312-321.

6. Wachyuni SS, Kusumaningrum DA (2020). The Effect of COVID-19 Pandemic: How are the Future Tourist Behavior? Journal of Education, Society and Behavioural Science 33(4): 67-76.

7. Moreno González A A, León C J, Fernández Hernández C (2020) Health destination image: The influence of public health management and wellbeing conditions. Journal of Destination Marketing and Management 16.

8. Mohd Ayob N, Masron T (2014) Issues of Safety and Security: New Challenging to Malaysia Tourism Industry. SHS Web of Conferences 12.

9. Kôvári I, Zimányi K (2011) Safety and security in the age of Global Tourism. Applied Studies in Agribusiness and Commerce (The changing role and conception of safety and security in tourism). 59-61.

10. Neuburger L, Egger R (2020) Travel risk perception and travel behaviour during the COVID-19 pandemic 2020: a case study of the DACH region. Current Issues in Tourism 1-14. 
11. Zou Y, Meng F (2020) Chinese tourists' sense of safety: perceptions of expected and experienced destination safety. Current Issues in Tourism 23(15): 1886-1899.

12. (2020) Update No. 199 Coronavirus disease (COVID-19). Ministry of Health.

13. Sandín B, Valiente RM, García Escalera J, Chorot P (2020) Psychological impact of the COVID-19 pandemic: Negative and positive effects on the Spanish population associated with the period of national confinement Journal of Psychopathology and Clinical Psychology 25(1).

14. Lasa NB, Benito JG, Manterola AG, Sánchez JPE, García JLP, et al (2020) The Consequences Psychological Of Covid-19 And Lockdown. Investigation Report.

15. Brooks S K, Webster R K, Smith L E, Woodland L, Wessely S, et al. (2020) The psychological impact of quarantine and how to reduce it: Rapid review of the evidence. The Lancet 395(10227): 912-920.

16. Wang G, Zhang Y, Zhao J, Zhang J, Jiang F (2020) Mitigate the effects of home confinement on children during the COVID-19 outbreak. The Lancet 395(10228): 945-947.

17. Rodríguez Rey, R Garrido Hernansaiz, H Collado S (2020) Psychological impact and associated factors during the initial stage of the coronavirus (COVID-19) pandemic among the general population in Spain. Frontiers in psychology 11: 1540 .

\section{ISSN: 2574-1241}

DOI: 10.26717/BJSTR.2020.30.004983

Theodore Metaxas. Biomed J Sci \& Tech Res

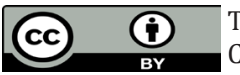

This work is licensed under Creative Commons Attribution 4.0 License

Submission Link: https://biomedres.us/submit-manuscript.php
18. Liu N, Zhang F, Wei C, Jia Y, Shang Z, et al. (2020) Prevalence and predictors of PTSS during COVID-19 outbreak in China hardest-hit areas: gender differences matter. Psychiatry Res 287: 112921.

19. Grecha V, Grech P, Fabric S (2020) A risk balancing act -Tourism competition using health leverage in the COVID-19 era', International Journal of Risk \& Safety in Medicine, 31(10223): 1-5.

20. Nunkoo R (2015) Tourism development and trust in local government. Tourism Management 46: 623-634.

21. Pyke S, Hartwell H, Blake A, Hemingway A (2016) Exploring well-being as a tourism product resource. Tourism Management 55: 94-105.

22. Yoo J J E, Chon K (2008) Factors Affecting Convention Participation Decision-Making: Developing a Measurement Scale. Journal of Travel Research 47(1): 113-122.

23. Nazneen S, Hong X, Ud Din N (2020) COVID-19 Crises and Tourist Travel Risk Perceptions. SSRN Electronic Journal.

24. Yu M, Li Z, Yu Z, He J, Zhou J (2020) Communication related health crisis on social media: a case of COVID-19 outbreak. Current Issues in Tourism.

25. (2020) World Development Indicators. DataBank.

BIOMEDICAL
RESEARCHES $\quad \begin{aligned} & \text { Assets of Publishing with us } \\ & \text { - Global archiving of articles }\end{aligned}$

